\title{
Is War Good for The United States: A Comparative Look at The U.S. and Ancient Rome Between Times of War and Conflict and the Economic Implications on Economic Well Being and Employment During Times of Peace Versus Conflict
}

\author{
Steven V. Cates and Jason Jackson
}

\begin{abstract}
War is an ugly thing, but not the ugliest of things: the decayed and degraded state of moral and patriotic feeling which thinks that nothing is worth a war, is much worse. This research analyzes existing data to review the impact on unemployment in the U.S. following each conflict and war it has been involved in. There is a comparison drawn to the Roman Economy and its dependence on war to and the economy of the U.S. and the causes of its ability to have economic success and the impact on unemployment of U.S. workers as a result.
\end{abstract}

Index Terms - unemployment, economy.

\section{INTRODUCTION}

There is much evidence that represents the US desired to imitate the Roman Republic (i.e. Roman sayings are on American currency, etc.). Which makes sense given that Rome "... managed to achieve a high standard of living through the combined operation of moderately stable political conditions and markets for goods, labor and capital, which allowed specialization and efficiency" [1]. The Roman Republic set the idolized standard of how to effectively run their government (or so they thought at the time), which American leaders saw value in imitating some of the same procedures. There are very similarities between the US and the economy that can be linked back to Roman History [1].

In reference to regarding poor economic conditions while not at war stems from the fact that the US is constantly at war. The US economy spends trillions of dollars on funding these initiatives that when the war is prolonged, it only increases the budget deficit. Brown University (n. d.) states that the US wars have almost been paid for entirely by borrowing, which only increases the national debt. Similarly, the Roman wars were constantly continuing and on the rise. These wars created tremendous financial hardships on Rome and eventually led to their financial collapse.

Even when the US is not actively in war, they have incurred so much debt that it impacts entire US economy

Published on October 17, 2020.

Steven V. Cates, Purdue University Global, USA

(corresponding e-mail: scates ${ }^{\circledR}$ purdueglobal.edu)

Jason Jackson, Purdue University Global, USA and the employees suffer due to higher unemployment [1].

\section{Statement Of The Problem}

The history of the U.S. has been marked with economic recession and depression since its beginning in 1700's. This research will analyze timelines from the beginning of the country to present and compare economic conditions of employment and unemployment as a variable of employee well-being to those periods of war and conflict to determine if there is a correlation between war and employee wellbeing as measured by unemployment. This will then be reviewed in comparison with Roman history to determine if the U.S. has followed a similar economic strategy [2].

\section{LITERATURE REVIEW}

\section{A. Comparative Analysis of the Ancient Roman Empire and the United States}

\section{Similarities}

The philosopher George Santayana once said: "Those who cannot remember the past are condemned to repeat it." To which might be added that those who remember Santayana's maxim also seem condemned to repeat the phrase [3].

Murphy [4] states in Are We Rome? there are many similarities and differences between the Roman Empire and America.

Dominant powers: "Rome and America have been the most powerful factors in their respective times. Their power parallels each other in military might and the 'soft power' of language, culture, commerce, technology, and ideas."

Approximately equal in size: "Rome and America are comparable in physical size - the Roman Empire and its Mediterranean lake would fit inside the three million square miles of the Lower Forty-eight states, though without a lot to spare."

Global influence: Rome and America created global structures - administrative, economic, military, cultural that the rest of the world and their own citizens took for granted.

Open society: Both Rome and the US were societies made up of many peoples. They were historically open to newcomers. They have been willing to absorb the lifestyles and deities of everyone else while granting citizenship to persons from all areas of the globe. 
Culturally similar: Romans and Americans were fixated on laws and lawyers and lawsuits. They both relished the ritual humiliation of public figures: Americans through comedy and satire, talk radio and social media while the Romans through vicious satire which was done during the republic by means of the censorial nota, which was the public airing, name by name, of everything great men of the time should be ashamed of."

Chosen people: Both Rome and the US saw themselves as chosen people and both see their national character as exceptional to all other nations.

\section{The Dole}

As a point of reference, the population of the Roman Empire, as recorded in the Roman Census, ranged from 84,700 citizens, under King Servius Tullius, prior to 508 B.C. to over 6.9 million citizens in 47 A.D. [5]. One of the key components of the start of economic instability with the Roman Economy started with the best of intentions, reform and the proper use of the city-state power structure to provide for citizenry. As the Roman Empire grew, it could product grain more effectively than the individual, and providing grain as a food source to citizens was value added benefit of the formation of larger social groups into one of the first large societies. As mentioned in the research of Garnsey and Rathbone [6], the contemporary orator and poet Florus remarked "what could be more just than that a people in need should be maintained from its own treasury?" The root of this policy in law, where grain was distributed at a determined fixed cost to the citizens, is the lex Sempronia frumentaria or the Grain Law created by Gaius Gracchus in 123 B.C. [7].

However, each successive politician would have the natural inclination to appear more generous than their political predecessor. So, this by its very nature creates an unsustainability, a race to more, when perhaps the system cannot support more. At some point a politician would make a promise that the nation could not live up to with the grain law policy. This is compounded by the reality that with success, the empire was growing in population over time. It was also kept in place by the societal masses. This is stated succinctly, "The political lesson was plain. Mass relief, once granted, created a political pressure group that nobody dared to oppose [8]."

The Grain Law can be encapsulated as an unstable economic cycle that was unsustainable. This is illustrated well by the following paragraph:

"Roman economic imbalance was an ongoing inability to match its fiscal outlays with available revenues. Like most rich nations today, Rome made fiscal commitments that it could not square with taxation, with monetary debasement, or with dictatorial central planning. It tried all three in that order, before its collapse. Rome's fiscal problems and political erosion has origins in the second century B.C., when the satirist Jevenul ridiculed the selling of votes by an infantile public in exchange for panem et circenses-bread and circuses [9]."

The Grain Law is an excellent historical example, from the Roman Empire, that illustrates the dangers of unsustainable economic policy. This serves as a cautionary tale to the societies the follow it in history, to include the United States.

\section{Methodology}

Research looks at five major factors to determine the health of a nation's economy. Inflation: Inflation measures the cost of goods and services. Inflation has a key effect on economies and markets. For economies, high inflation discourages savings and investment, leads to higher interest rates, and ultimately limits growth. Employment: People with jobs can spend and invest. Ultimately, both of these actions are needed to drive the economy Housing: In a land of increasing house prices, banks lend and the economy booms. However, the housing game has changed. Having lived through the housing collapse, I expect banks to become more prudent for many years. Spending: We live in a consumption-based society. As consumers increase their expenditures, the economy grows. Confidence: Although it is elusive, confidence drives everything. When people are confident, they spend, and the economy grows.

For purposes of this research the focus will be on employee employment and unemployment as indicators of economic health from a human resources perspective and how they compare with timelines of conflict and war the US has been involved".

\section{FINDINGS}

The colonial economy of what would become the United States was pre-industrial, primarily characterized by subsistence farming. Farm households also were engaged in handicraft production, mostly for home consumption, but with some goods sold.

World peace lasted only a decade, for in 1793 a twodecades of war between Britain and France and their allies broke out [10]. As the leading neutral trading partner the United States did business with both sides. France resented it, and the Quasi-War of 1798-99 disrupted trade. Outraged at British impositions on American merchant ships, and sailors, the Jefferson and Madison administrations engaged in economic warfare with Britain 1807-1812, and then fullscale warfare 1812 to 1815 [11].

There were three economic downturns in the early 19th century. The first was the result of the Embargo Act of 1807, which shut off most international shipping and trade due to the Napoleonic Wars. The embargo caused a depression in cities and industries dependent on European trade. This resulted in mass unemployment as a result [12].

The second downturn was a depressions accompanied by significant period of deflation during the early 19th century. The first and most severe was during the depression from 1818 to 1821 when prices of agricultural commodities declined by almost 50 percent [13]. A credit contraction caused by a financial crisis in England drained specie out of the U.S. and The Bank of the United States also contracted its lending. The price of agricultural commodities fell by almost 50 percent from the high in 1815 to the low in 1821 , and did not recover until the late $1830 \mathrm{~s}$, although to a significantly lower price level. Most damaging was the price of cotton, the U.S.'s main export. Food crop prices, which had been high because of the famine of 1816 that was caused by the year without a summer, fell after the return of normal harvests in 1818. Improved transportation, mainly 
from turnpikes, significantly lowered transportation costs [13]. This resulted in a tickle effect on employment and caused large numbers to be unemployed during this time.

This was a result of The War of 1812 which was waged against the British and their respective allies from June 1812 to February 1815. Across the two and half years of the war, $1812-1815$, the federal government took in more money than it spent. This war action actually increased employment in both creations of war goods as well as cotton and food supplies such as beef, pork, and vegetable crops. Due to the decrease in demand of these goods after the War of 1812 we see the effects of a deflation and a reduction in the need for labor and mass unemployment [14].

The third economic downturn was the depression of the late 1830 s to 1843 , following the Panic of 1837 when the money supply in the United States contracted by about 34 percent with prices falling by 33 percent. The magnitude of this contraction is matched only by the Great Depression of 1929-1935 [15].

A fundamental cause of the Panic of 1837 was depletion of Mexican silver mines. Despite the deflation and depression, GDP rose 16 percent from 1839 to 1843 , partly because of rapid population growth and the reduction in the cost of labor by severely reducing the labor costs to produce the goods and services [15].

The longest economic expansion of the United States occurred in the recession-free period between 1841-1856. This economic expansion came primarily to "a boom in transportation-goods investment following the discovery of gold in California." [16].

The recovery from the depression that followed the Panic of 1837 began in 1841 and lasted until the Panic of 1857 [16].

The Panic pf 1857 left many northern wage earners unemployed, most temporarily, but high unemployment lingered for a couple of years. Irish Immigration during this time due to the Great Potato Famine created mass unemployment. The South also began to collapse in late 1850's as well and created mass unemployment [17], [18].

In 1860 tensions grew between northern and southern legislators over not only slavery but trade issues from the large farming interests in the south and the industrial facilities that relied on those raw goods to keep the factories running [17], [18].

Historians have debated whether or not the Civil War sped up the rate of economic growth in the face of destruction throughout the South and the diversion of resources to military supplies and away from civilian goods. In any case the war taught new organizational methods, prioritized engineering skills, and shifted the national attention from politics to business [17], [18].

Unemployment was not an issue during the War Between the States due to the need for every available person to work towards keeping the respective armies supplied. In fact, the Union grew rich fighting the war, as the Confederate economy was destroyed [19].

The result of this war was a depression that occurred in 1869. This created mass unemployment and created great stress on the economy of the north and the reconstruction in the south [19].

The Panic of 1873 created one of the worst and longest depressions in American history, seriously affecting every aspect of the economy and bringing the railroad expansion to a halt. Mass unemployment was a result of this Depression [20].

The US was barely recovering when the Panic of 1893 , another deep depression, that lasted until 1897. This Depression created mass unemployment and left thousands homeless and hungry [21].

A major economic downturn in 1906 ended the expansion from the late 1890s. This was followed by the Panic of 1907. The Panic of 1907 was a factor in the establishment of the Federal Reserve Bank in 1913 [21].

The Sixteenth Amendment to the United States Constitution, which allowed the Federal Government to tax all income, was adopted in 1913 [22].

The period from 1893 to 1910 was one of rapid economic growth in part due to rapid population growth. However, a sharp break in the growth rate to around $2.8 \%$ occurred from 1910 to 1929 [23].

The U.S. economy prospered during World War I, partly due to sales of war goods to Europe. The stock market had its best year in history in 1916 [24].

The US involvement in World War I in 1918-1919 can be attributed to the improved economic growth but with thousands of soldiers being drafted and volunteering for war the growth rate dropped rapidly) [24], [25].

It is generally accepted that the new technologies and more efficient business methods permanently shifted the supply and demand relationship for labor, with labor being in surplus except during both world wars when the economy was engaged in war-time production and millions of men served in the armed forces [26].

The Emergency Quota Act (1921) established a quota system on immigrants by country of origin, with the maximum number of annual immigrants from a country limited to $3 \%$ of the number of that national background living in the U.S. The Immigration Act of 1924 reduced the quota from $3 \%$ to $2 \%$ and added additional restrictions on certain nationalities [27].

1920-1929 is known as the Roaring Twenties. This was a period of prosperity, along with the culture of the time. The workweek, which averaged 53 hours in 1900, continued to decline during this time. Then Wall Street crashed in 1929. This started the Great Depression from 1929-1941 [27].

\section{A. Unemployment}

Unemployment reached 25 percent in the worst days of 1932-33, but it was unevenly distributed. Job losses were less severe among women than men, among workers in nondurable industries (such as food and clothing), in services and sales, and in government jobs. The least skilled inner city men had much higher unemployment rates, as did young people who had a hard time getting their first job, and men over the age of 45 who if they lost their job would seldom find another one because employers had their choice of younger men. Millions were hired in the Great Depression, but men with weaker credentials were never hired, and fell into a long-term unemployment trap. The migration that brought millions of farmers and townspeople to the bigger cities in the 1920s suddenly reversed itself, as unemployment made the cities unattractive, and the network 
of kinfolk and more ample food supplies made it wise for many to go back [28].

City governments in 1930-31 tried to meet the depression by expanding public works projects, as president Herbert Hoover strongly encouraged. However, tax revenues were plunging, and the cities as well as private relief agencies were totally overwhelmed by 1931 , they were unable to provide significant additional relief. They fell back on the cheapest possible relief, soup kitchens which provided free meals for anyone who showed up. After 1933 new sales taxes and infusions of federal money helped relieve the fiscal distress of the cities, but the budgets did not fully recover until 1941 [28].

The federal programs launched by Hoover and greatly expanded by president Roosevelt's New Deal used massive construction projects to try to jump start the economy and solve the unemployment crisis. The alphabet agencies ERA, CCC, FERA, WPA and PWA built and repaired the public infrastructure in dramatic fashion but did little to foster the recovery of the private sector. FERA, CCC, and especially WPA focused on providing unskilled jobs for long-term unemployed men [28].

From 1940 to 1945 , during World War II, unemployment dropped to $2 \%$, relief programs largely ended, and the industrial economy grew rapidly to new heights as millions of people moved to new jobs in war centers, and 16 million men and 300,000 women were drafted or volunteered for military service. All economic sectors grew during the war [29].

World War II was financed through debt and higher taxes, by the end of the war, U.S. gross debt was over $120 \%$ of GDP and tax revenue increased more than three times to over $20 \%$ of GDP. Although GDP growth skyrocketed to over $17 \%$ in 1942 , both consumption and investment experienced a substantial contraction. One of the key causes was government control of raw resources and materials. Trend lines taken from before the war and dating from 1933 onwards clearly indicate that for investment, consumption, and GDP growth there was no increase in the trend lines after the war had finished. While unemployment was virtually eliminated, recovery was well underway prior to the war, and the key counterfactual is whether similar spending on public works would have generated even more growth. The stock market initially dropped and once victory was foreseeable then rose to be higher than at the start of the war [29].

What resulted as an aftermath to World War II is the US experienced in1948-49 another economic recession [29].

From 1950 to 1953 , the US was involved in the Korean War. The Korean War was largely financed by higher tax rates with GDP averaging 5.8 percent between 1950 and 1953 with GDP growth peaking at 11.4 percent in 1951 . During this period however, investment and consumption stalled. The government needed to implement price and wage controls in response to inflation which had increased due to the additional stimulus that was created by government spending. Notably, both consumption and investment resumed growing after the war; however the growth was below the trend rate prior to the war. The stock market rose during the war [30].

In 1957 the US enters a deep economic depression. This signals the end of union growth in the U.S. [31].

As a result, the U.S. entered the Vietnam Conflict (War) in 1958 by order of President John Kennedy sending the first troops as economic advisors to the South Vietnamese [31]. The Vietnam War was unlike World War II and the Korean War, as it ramped up slowly with American troop deployments starting in 1965. This war was largely funded by increases in tax rates, but also with an expansive monetary policy which then subsequently led to inflation. Increases in non-military outlays also had a role to play. Unlike prior wars, consumption remained unaltered due to expansionary monetary policy although investment fell during the war. Again, as with the two prior wars, GDP growth increased and peaked at 7.3 percent of GDP in 1966. At the beginning of 1965, the Dow Jones index was at 900 and it wasn't until after October 1982 that it regained, stable, above the 900 mark. The Vietnam Conflict lasted from 1960-1973 [31], [32].

In 1972, the US experienced the OPEC Oil Embargo. The 1973 oil crisis began which caused productivity growth to fall to a low level after 1973 and remained low until the 1990s. This created the 1973-1974 stock market crash. This resulted in Unemployment to rise sharply. Unemployment dropped mostly steadily from 1975 to 1979 as the economy attempted to prosper on its own without wartime support although it then began to rise sharply. Inflation began a steep rise beginning in late 1978 and rose by double digits following the 1979 energy crisis [33].

The Cold War period can be categorized as running from the late 1970s through to 1989. This period saw sustained increases in military spending alongside tax cuts which then resulted in a blowout in the budget deficit. Although there was a boom in consumption it was fueled by a combination of increased deficit spending and higher government debt which in turn also caused interest rates to increase. This was also accompanied by a substantial trade deficit as well as a bull run with the Dow Jones index increasing from 1,121 in February 1983 to 2,810 in January 1990 [34].

In 1980 recession occurs. Manufacturing shed 1.1 million jobs, while service industries remained intact. Employment in automotive manufacturing in particular suffered, experiencing a 33 percent reduction by the end of the recession. Unemployment rose to a peak of 10.8 percent in December 1982, a post-war high. However, unemployment dropped to well under 6 percent the by end of the Reagan Presidency in January 1989 [35].

An economic boom took place from 1983 until a recession began in 1990. Between 1983 and 1989 the number of people below the poverty line decreased by 3.8 million [35].

In 1990-1991 the US entered the first Gulf War, also known as Operation Desert Shield and Operation Desert Storm. The Afghanistan and Iraq Wars were accompanied by weak economic conditions right from their beginning and corresponded with the bursting of the high tech asset bubble which led to the 2001-2002 recession. This was also the first time in U.S. history where taxes were cut during a war which then resulted in both wars completely financed by deficit spending. A loose monetary policy was also implemented while interest rates were kept low and banking regulations were relaxed to stimulate the economy. All of 
these factors have contributed to the U.S. having severe unsustainable structural imbalances in its government finances [36], [37].

As a result of the US being involved in these wars, from 1991-2000, unemployment dropped to below 5\%.

In 2003-present the US has been involved in the IRAQ War. As a result of our long term involvement in this action we changed drastically our lending and borrowing laws to allow the economy to flourish. As a result, we experienced one of worst downturns in our economy since The Great Depression.

During 2007 to 2009, we began the Great Recession. In the US during this time jobs paying between \$14 and \$21 per hour made up about 60 percent of those lost during the recession, but such mid-wage jobs have comprised only about 27 percent of jobs gained during the recovery through mid-2012. In contrast, lower-paying jobs constituted about 58 percent of the jobs regained. Therefore, people actually have lower wages and a lower standard of living than they experienced twenty years prior to this period. From 2008 to 2009, the U.S. labor market lost 8.4 million jobs, or 6.1 percent of all payroll employment.

Today, the U.S. is officially fighting wars in seven countries, including Libya and Niger, according to an unclassified White House report sent to Congress obtained by the New York Times.

Is this the reason for our robust economy right now?

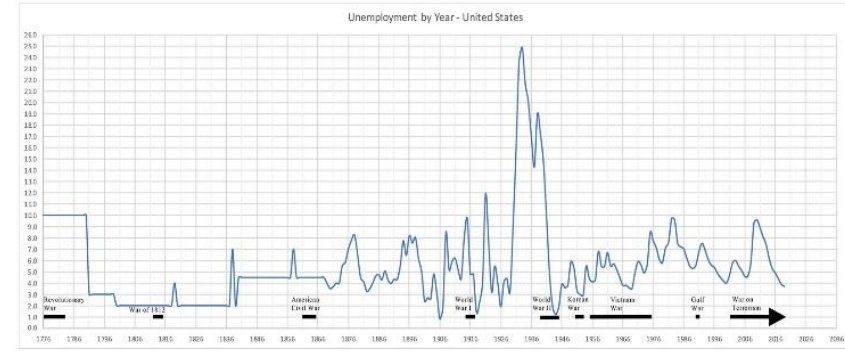

Fig. 1. Unemployment Rate by Year with Major Wars of the United States of America.

\section{B. Data}

One of the main outcomes of this study is represented in Figure 1, Unemployment by Year - United States. This chart starts at 1776 and continues to the present 2019 with a vector towards the future. Data for the chart is current as of August 2019 unemployment data, with an average of the eight months of the year, January 2019 - August 2019 utilized for 2019 unemployment data. Both the 2019 dataset and the 2018 to 1948 dataset are from the Bureau of Labor and Statistics [38], [39]. It should be noted that the population of these two datasets are working individuals ages 16 and older. The format for the data was an integer followed by one decimal point value, such as: 3.7 representing 3.7 percent unemployment for a given month.

The dataset for 1947 to 1900 was provided by the National Bureau of Economic Research [40]. The data entry element Percent of Civilian Labor Force was utilized and formatted similarly via integer with one decimal point value. This dataset population was working individuals ages 14 years and older.

The dataset for 1899 to 1869 was based on the published research of J.R. Vernon, University of Florida, Gainesville,
Florida: Unemployment Rates in Postbellum America: 1869-1899 [41]. This data was provided in the format of one integer with two decimal points, such as 3.29 and then was rounded, using standard rounding rule behavior to 3.3 to match the other datasets. This dataset was for a population of working individuals aged 14 year and older.

The dataset for 1868 to 1800 was from the book, Manpower in Economic Growth [42]. Data was formatted as ranges, such as 1-3, as percent averages for decade averages, and range averages as well for more focused data during years of economic panic or crisis. The reason being, that this data was not of much concern at this time, unless during a crisis or panic, where it then received more attention by government and society. While not formally stated, it is not surprising that otherwise data is in decade average format, given the probable connection to the national census every ten (10) years. The median value of each range was used, so a range of 1-3 was converted to 2.0 to match prior data. This dataset was for a population of working individuals aged 14 years and older. However, it should be noted that as the history works backward, younger individuals were more often expected to work, and it would not be surprising to expect children as young as 10 to work during this timeframe. Additionally, as this is a timeframe that extends back prior to the United States Civil War, and in particular the Emancipation Proclamation (1863) that slavery and also indentured servitude were factors connected to the behavior of unemployment for this dataset and earlier in history.

The dataset for 1799 to 1776 was based on a narrative format article (U.S. Department of State, 2018), compared to the narrative discussion on data analysis provided by Lebergott [42] and an appreciation that this was not only a war, it was the start of a new nation, hence at least as difficult as a war. Also, an appreciation that it was a primarily agrarian society, near the 90 percent farming mark, with 10 percent city business or industry. This was bolstered by some research via Bureau of Labor and Statistics data and their link to the census data-related book, Historical Statistics of the United States, 1789 to 1945 [43]. Similar to the prior dataset, the researchers determined to use similar decade averages. It was not uncommon in later timeframes as covered by Lebergott [42] that unemployment would reach up to 10 percent in cities, when the focus was on non-farming industries (or businesses). We determined that this was viable prior to 1800 , hence utilized a 10 percent estimate for 1776 to 1790 . Also, given that as the vast majority of working aged individuals were farmers, if their city employment failed, they could fallback quickly on their farming skills and return to the agrarian economy as primary, in essence making these individuals self-employed versus unemployed. Hence, we assigned a 3 percent estimate for 1791 to 1799 . This is visual represented by the starting data on the far left of the chart, the initial 10 percent plateau, then the immediately following 3 percent plateau.

As an artifact of data science, it is interesting to observe the chart going back in time from the far right (2019) to the far left (1776). As we go back into history, data is much more difficult to determine, and in the time that it was lived was not taken with the benefits we have today with information systems and self-recording sensors. The visual cues of this chart show the different datasets, as the data gets 
less precise going back into time. The data is still accurate, just less precise. The spikes and plateaus of crisis years and decade averages map differently than the more precisely measured data with slight motions of curves from World War II to the present 21 st Century.

\section{CONCLUSION}

The chronological timeline of the US economy is very similar to what Rome experienced during the time it was a war-driven economy. When Rome chose to attempt a strategy of living in peace it found its economy was unsustainable and led to the eventual collapse of Rome and it defeat at the hands of Hannibal.

The timeline provided in this research clearly shows the US economy prospers only when it is at war. It funds war efforts through heavy debt and borrowing which leads to an economic recession or depression within five years of ceasing it support for that specific war effort. This has been the economic pattern since 1778 and has been very consistent over time.

It is shown that the US economy is very similar to the Roman economy based on its predisposition for war and driving economic growth through war.

The unemployment rate has followed economic patterns consistently over time in that unemployment is low when the US is at war but suffers within five years of the end of that conflict. Therefore, the US has consistently entered into a new war to attempt to revive and sustain the economy based on its historical patterns.

\section{REFERENCES}

[1] Temin, P. (2006). The economy of the early Roman Empire. The Journal of Economic Perspectives, 20(1), 133 151.doi:http://dx.doi.org.ezproxy.liberty.edu/.

[2] Cain, Louis P., Price V. Fishback and Paul W. Rhode, (2018), eds. The Oxford Handbook of American Economic History ,2 vol Oxford Up, pp. 961 pp.

[3] Santayana, G., (1905), Book of Common Sense, Internet Encyclopedia of Philosophy, https://www.IEP.com.

[4] Murphy, S., (2017), Other People's Money: How Banking Worked in the Early American Republic.

[5] Adams, J.P. (2010). Roman Census Figures. Found online at: https://www.csun.edu/ hcfll004/romancensus.html.

[6] Garnsey, P. \& Rathbone, D. (1985). The background to the Grain Law of Gaius Gracchus. The Journal of Roman Studies, (Vol. 75, pp. 20-25).

[7] Aly, S. (2017). The Gracchi and the era of grain reform in Ancient Rome. Tenor of our times (journal): Vol. 6, Article 6.

[8] Hazlitt, H. (1971). Poor relief in Ancient Rome. Found online at: https://fee.org/articles/poor-relief-in-ancient-rome/.

[9] Hubbard, R. G., \& Kane, T. (2014). Balance: The economics of great powers from ancient Rome to modern America.

[10] McCusker, John J. and Russell R. Menard. The Economy of British America, 1607-1789 (1991).

[11] Daggett, S. (2010), Congressional Research Service: Costs of Major U.S. Wars, Federation of American Scientists, viewed 1 October 2011, http://www.fas.org/sgp/crs/natsec/RS22926.pdf.

[12] Gordon, J., 2004), An Empire of Wealth: The Epic History of American Economic Power.

[13] Atack, J., Passell, P., (1994). A New Economic View of American History: From Colonial Times to 1940. New York: W.W. Norton and Co. ISBN 978-0-393-96315-1.1st edition

[14] Browning, Andrew H. (2019), The Panic of 1819: The First Great Depression, Comprehensive scholarly history of the era in the United States.

[15] Sellers, C., (1994), The Market Revolution: Jacksonian America, 1815-1846.
[16] Meyer, B. and MacGill, C., (1917), History of Transportation in the United States before 1860).

[17] Gordon, R. (2016). The Rise and Fall of American Growth. Princeton, NJ USA: Princeton University Press., ISBN 978-0-691-14772-7.

[18] Gordon, R., (2016), The Rise and Fall of American Growth: The U.S Standard of Living since the Civil War.

[19] Fite, E., (1910), Social and industrial conditions in the North during the Civil War.

[20] Chernow, R. (2001), The house of Morgan: an American banking dynasty and the rise of modern finance.

[21] Faulkner, H. (1937), U. Economic history of the United States.

[22] Misa, T., (1995), A Nation of Steel: The Making of Modern America, 1865-1925

[23] Carson, T., (1999), Gale Encyclopedia of U.S. Economic History.

[24] Garrett-Peltier, H. \& Pollin, R. (2009), The U.S. Employment Effects of Military and Domestic Spending Priorities: An Updated Analysis, Political Economy Research Group (PERI), University of Massachusetts, viewed 1 October 2011, http://www.peri.umass.edu/fileadmin/pdf/published_study/spending_ priorities_PERI.pdf.

[25] Soule, G., (1947), The Prosperity Decade: From War to Depression, 1917-1929.

[26] Cosgrove-Mather, B. (2009), Poll: Worries Over War And Economy, February 11, CBS News, http://www.cbsnews.com/stories/2003/02/13/opinion/polls/main5405 74.shtml.

[27] Woytinsky, W.S. (1995)), World commerce and governments: Trends and outlook, 907pp., United States Department of State , us.gov.

[28] Morris, C. (2017), A Rabble of Dead Money: The Great Crash and the Global Depression: 1929-1939, PublicAffairs, 389 pp.

[29] Labonte, M. (2004), CRS Report for Congress: Financing Issues and Economic Effects of American Wars, http://www.ndu.edu/library/docs/crs/ crs_r131176_27apr04.pdf.

[30] Edelstein, M., (2000), War and the American Economy in the Twentieth Century, pp. 329-405 in S.L. Engerman and R.E. Gallman, eds. The Cambridge Economic History of the United States. Vol. III. The Twentieth Century. Cambridge University Press.

[31] Stiglitz, J. (2003). The myth of the war economy. Retrieved August 12, 2010, from The Guardian: http://www. guardian.co.uk/politics/2003/jan/22/iraq.economy.

[32] French, M., (1997), US Economic History since 1945

[33] Wilson, C. (1981), Our Dance Has Turned to Death (Carol Stream, IL: Tyndale, pp. 84-85.

[34] Higgs, R. (2011). Depression, War, and Cold War: Studies in Political Economy. Oxford University Press. New York Institute for Economics and Peace.

[35] Walton, G. Rockoff, H., (2012), History of the American Economy with Economic Applications.

[36] Stiglitz, J. \& Blimes, L. (2011) Estimating the costs of war: Methodological issues, with applications to Iraq and Afghanistan. Chapter 13, Oxford Handbook of the Economics of Peace and Conflict

[37] Yarrow, A., (2006), "The big postwar story: Abundance and the rise of economic journalism.", Journalism History, 32.2, 58.

[38] BLS - Bureau of Labor and Statistics (2019). Unemployment rate: time series data. Found online at: https://data.bls.gov/timeseries/LNS14000000.

[39] BLS - Bureau of Labor and Statistics (2018). Employment status of the civilian population 1948 to date. Found online at https://www.bls.gov/cps/cpsaat01.pdf.

[40] NBER - National Bureau of Economic Research (1957). The measurement and behavior of unemployment (pp. 215-216). Found online at: http://www.nber.org/books/univ57-1

[41] Vernon, J.R. (1994). Unemployment rates in Postbellum America: 1869-1899. Journal of Macroeconomics, (Fall 1994, Vol. 16, No. 4 pp. 701-714). Louisiana State University Press.

[42] Lebergott, S. (1964). Manpower in economic growth: The American Record since 1800. New York: McGraw-Hill Book Company.

[43] United States Department of Commerce (1949). Historical Statistics of the United States, 1789-1945. Found online at: https://www2.census.gov/prod2/statcomp/documents/HistoricalStatist icsoftheUnitedStates1789-1945.pdf. 